\title{
PERAN TRANSPORTASI MRT DALAM MENDUKUNG INDUSTRI PARIWISATA BISNIS DI JAKARTA
}

\author{
Made Handijaya Dewantara \\ Email: made.handijaya@pmbs.ac.id \\ UNIVERSITAS PRASETIYA MULYA
}

\begin{abstract}
This study sets an objective to examine the role of MRT transportation (mass rapid transit) in supporting the tourism (business) industry in Jakarta. This research uses a descriptive qualitative approach. Data collection techniques were carried out for two weeks through indepth interviews and participatory observation techniques. Data obtained from the study results were analyzed using descriptive models. Data obtained was then adjusted to the PEST (PEST Analysis) theory and described through the business model canvas. Results showed that the MRT Jakarta is an appropriate type of public transportation to facilitate the accessibility of tourists while on vacation, as well as doing business in Jakarta. MRT Jakarta has also changed the new way of behavior and transform a civilization of people of Jakarta, to be more orderly, disciplined, and prefer to take public transportation. This will reduce potential air and noise pollution in Jakarta. With a value proposition on its business model canvas which shows a new type of public transportation that is fast, environmentally friendly, free of traffic jam, and hightechnology, MRT Jakarta is expected to be the most favorite transportation for tourists, whether they are in business, or enjoying tourist attractions in the capital city. In the future, PT MRT Jakarta is asked to continue the next railroad construction process, while maintaining excellent service standards that have been applied.
\end{abstract}

Keywords: Transportation, Accessibility, Service, Value Proposition

\begin{abstract}
Abstrak
Penelitian ini bertujuan untuk mengkaji peran transportasi MRT (mass rapid transit atau moda raya terpadu) dalam mendukung industri pariwisata bisnis di Jakarta. Pendekatan yang digunakan dalam penelitian kali ini merupakan bentuk pendekatan deskriptif kualitatif. Teknik pengumpulan data dilakukan selama dua minggu melalui wawancara mendalam dan teknik participatory observation. Data yang diperoleh dari hasil penelitian, dianalisis dengan menggunakan model deskriptif. Datadata yang diperoleh kemudian disesuaikan dengan teori PEST (PEST
\end{abstract}


Analysis), untuk kemudian dideskripsikan melalui business model canvas. Hasil penelitian menunjukkan bahwa MRT Jakarta merupakan jenis transportasi yang tepat dalam memperlancar aksesibilitas wisatawan selama berlibur, maupun berbisnis di Jakarta. MRT Jakarta juga telah mengubah cara berperilaku dan mengubah peradaban masyarakat Jakarta, untuk lebih tertib, disiplin, dan menyukai transportasi publik. Hal ini akan mengurangi potensi polusi udara dan bunyi di Jakarta. Dengan value proposition dalam business model canvas yang menunjukkan moda transportasi yang cepat, ramah lingkungan, tanpa macet, serta berteknologi tinggi, MRT Jakarta diperkirakan akan menjadi primadona para wisatawan, baik yang sedang berbisnis, maupun yang sedang menikmati daya tarik wisata di ibukota Jakarta. Untuk ke depannya, PT MRT Jakarta diminta untuk tetap melanjutkan proses konstruksi rel berikutnya, sembari mempertahankan standar pelayanan prima yang selama ini sudah diterapkan.

Kata Kunci: Transportasi, Aksesibilitas, Pelayanan, Value Proposition

\section{Pendahuluan}

Sebagai pusat kota dari pemerintahan dan perdagangan Indonesia, Jakarta adalah magnet bagi setiap orang, baik di Indonesia, maupun luar negeri, dalam melakukan aktivitas bisnis. Setiap harinya, berdasarkan data Dinas Perhubungan, tidak kurang dari 5 juta orang bepergian dari daerah sekitar Jakarta, seperti Bogor, Tangerang, dan Depok, dengan menggunakan moda transportasi publik (seperti bus TransJakarta, Kereta Rel Listrik (KRL), transportasi online, dan taksi), hingga kendaraan pribadi. Dengan adanya ekspansi-ekspansi di daerah Jakarta dan Jabodetabek, biaya transportasi semakin meningkat pesat sementara tingkat mobilitas dan kualitas tempat tinggal semakin menurun. Di saat yang sama, Jakarta juga menjadi tujuan wisatawan utama kedua setelah Bali. Sebagian besar wisatawan asing maupun domestik yang berkunjung ke Jakarta, bertujuan untuk bisnis, atau business traveler. Kebutuhan business traveler akan moda transportasi yang cepat dan ramah pada turis pun menjadi mutlak. 
Berbeda dengan destinasi ibukota negara di beberapa negara tetangga, seperti Bangkok, Kualalumpur, Manila, atau Singapura, Jakarta mempunyai ketertinggalan dari segi penyediaan sarana transportasi publik. Meningkatnya tingkat wisatawan bisnis, atau MICE, mendorong pemerintah pusat dan provinsi Jakarta untuk membangun transportasi yang lebih baik, cepat, aman, nyaman dan aksesibilitas yang lebih tinggi untuk menjawab permasalahan tentang mobilitas dari masyarakat. Dengan efektifitas dan efisiensi dari sistem railway, dan melihat karakteristik ibukota negara tetangga, transportasi publik berjenis Mass Rapid Transit atau Moda Raya Terpadu (MRT) dipandang sebagai solusi yang paling tepat untuk memecahkan permasalahan ini. Hal ini sejalan dengan Peraturan Daerah Provinsi Daerah Khusus Ibukota Jakarta Nomor 3 Tahun 2008, tentang Pembentukan Badan Usaha Milik Daerah (BUMD), Perseroan Terbatas (PT) MRT Jakarta.

MRT Jakarta adalah transportasi yang dipandang sangat cocok dan memiliki arahan yang jelas dalam menargetkan peningkatan kualitas hidup masyarakat, sekaligus mobilitas wisatawan secara umum. MRT juga dipercaya mampu membawa Jakarta ke dalam derajat yang lebih tinggi untuk dapat bersaing atau menyamakan sistem transportasi luar negeri. Dari hal ini, MRT Jakarta dipandang mampu memposisikan diri untuk membuat Jakarta layak bersaing sebagai kota tujuan pariwisata bisnis, yang menyediakan sistem transportasi yang cepat, aman, dan nyaman untuk masyarakat. Hal ini tentu berhubungan dengan tagline MRT Jakarta yaitu 'Meningkatkan mobilitas, peningkatan kualitas hidup'.

Awal dimulainya konstruksi MRT Jakarta diselenggarakan dengan acara grand opening yang dilaksanakan pada tanggal 10 Oktober 2013, di Jl. Thamrin, Dukuh Atas, Jakarta Pusat. Saat itu, pembangunan dari MRT Jakarta adalah mendukung pertumbuhan ekonomi dan percepatan pembangunan infrastruktur di Indonesia. Perusahaan ini diharapkan 
mampu menyediakan transportasi yang sangat cepat, nyaman, aman, serta mampu diandalkan untuk masyarakat, serta meningkatkan prestise Jakarta sebagai tujuan wisata metropolitan. Pembangunan MRT juga diharapkan meningkatkan pertumbuhan dan peluang revitalisasi untuk daerah sekitar stasiun tempat bertransit dan sepanjang koridor MRT, selain meminimalisir kemacetan dan polusi yang dihasilkan oleh transportasi lain. MRT Jakarta juga diharapkan mampu mempermudah mobilitas, baik warga Jakarta, maupun wisatawan asing, yang sedang melakukan aktivitas bisnis di Jakarta.

MRT Jakarta ternyata mampu menciptakan ribuan pekerjaan, utamanya selama konstruksi berlangsung dan sesudah operasi MRT Jakarta berjalan. Mobilitas di Jakarta akan mengalami pertumbuhan yang akan meningkatkan kualitas hidup masyarakat. Selain itu, dampak lingkungan dari pembuatan MRT Jakarta salah satunya adalah mengurangi konsumsi gas fosil yang selama ini menjadi penyumbang polusi udara. Polusi udara selama ini selalu menjadi hambatan Jakarta dalam menarik minat wisatawan untuk tinggal lebih lama di Jakarta. Adanya model MRT Jakarta yang menggunakan sistem transit di setiap stasiun, diperkirakan dapat menggerakan pertumbuhan ekonomi di daerah sekitar stasiun MRT.

MRT Jakarta kemudian dikelola oleh PT. MRT Jakarta yang merupakan perusahaan perseroan terbatas yang pemegang saham terbesarnya adalah pemerintah provinsi DKI Jakarta. Tugas utama dari PT. MRT Jakarta adalah membangun infrastruktur dan fasilitas MRT, baik dalam menyediakan sarana operasional maupun pemeliharaan MRT. Di sisi lain, PT MRT Jakarta juga diminta mengembangkan sekaligus mengatur properti dan bisnis yang terdapat di sekitar daerah stasiun dan daerah sekitarnya. Di antara properti dan bisnis tersebut, diharapkan juga menunjang kegiatan pariwisata, berbasis bisnis MICE (meeting, incentive, convention, and exhibition). 
Untuk memenuhi ekspektasi mobilitas tersebut, PT MRT Jakarta kemudian memulai fase konstruksi pertamanya dengan rute sepanjang 15,7 kilometer yang menghubungkan antara terminal Lebak Bulus dengan Bundaran Hotel Indonesia (Bundaran HI). Rute pertama ini terdiri dari 13 stasiun, di sepanjang rute, yang melewati beberapa pusat bisnis dan pusat mobilitas orang. PT MRT Jakarta juga bekerja sama dengan konsultan dari manajemen lalu lintas, untuk memastikan bahwa projek sudah menyesuaikan dengan dokumen analisis tentang dampak lingkungan. Hal ini menjadi aspek yang penting, mengingat isu lingkungan selalu menjadi tantangan pariwisata di Jakarta. Rute pertama MRT kemudian mulai dioperasikan pada tahun 2018. PT. MRT Jakarta mendesain MRT lebih baik dengan MRT yang ada di Bangkok, Kualalumpur, Manila, dan Singapura, dengan standar kualifikasi terbaik, pada moda maupun proses transaksi.

Segala ekspektasi yang disematkan pada manajemen MRT Jakarta sebenarnya tidak mengandung tantangan. Beberapa saat setelah MRT diresmikan, beberapa persoalan mulai bermunculan, seakan menguji kesiapan MRT untuk menjadi moda transportasi wisatawan bisnis di ibukota. Hasil pra wawancara kepada beberapa wisatawan asing menunjukkan beberapa permasalahan yang dialami oleh MRT Jakarta, sebagai salah satu moda transportasi pariwisata di Jakarta. Permasalahan pertama, sedikitnya destinasi wisata, seperti museum, gedung pertemuan, dan destinasi budaya, yang tidak terjangkau dengan MRT.

Selain permasalahan tersebut, kendala kedua adalah kurang terintegrasinya layanan MRT dengan moda transportasi lainnya, sehingga menyulitkan wisatawan ketika ingin melanjutkan perjalanannya. Kendala ketiga adalah persoalan teknis, baik di gerbang pembayaran, maupun di mesin tiket otomatis, yang terkadang mengalami kendala. Kendala 
keempat adalah tidak dilewatinya landmark khas Jakarta, seperti Monumen Nasional, dan Museum Nasional, pada jalur MRT.

Terlepas dari kendala yang dihadapinya, hasil pengamatan menunjukkan bahwa moda MRT sudah mulai diminati oleh wisatawan mancanegara, baik yang sedang berwisata untuk bersenang-senang (leisure) maupun untuk berbisnis. Antusiasme wisatawan mancanegara tersebut wajib direspons dengan baik, untuk membuat MRT semakin difavoritkan wisatawan mancanegara, sekaligus mendukung bisnis pariwisata di Jakarta. Hal tersebut merupakan sisi urgensi dilaksanakannya penelitian lapangan, mengenai MRT. Berdasarkan hal tersebut, penelitian ini bertujuan untuk mengkaji peran transportasi MRT dalam mendukung industri pariwisata bisnis di Jakarta.

\section{Metode Penelitian}

Pendekatan yang digunakan dalam penelitian kali ini merupakan bentuk pendekatan deskriptif kualitatif. Penelitian seperti ini tidak dimaksudkan untuk menguji hipotesis tertentu, tetapi melakukan deskripsi atas fenomena, maupun variabel, gejala, atau keadaan. Metode ini digunakan untuk memaparkan peran transportasi MRT, sebagai salah satu penunjang aksesibilitas wisatawan, yang dalam hal ini mendukung industri pariwisata bisnis di Jakarta. Penelitian dilakukan selama dua minggu, yaitu 10 sampai 24 Februari 2020, di beberapa stasiun MRT di Jakarta, dan beberapa pusat bisnis yang melibatkan wisatawan bisnis di Jakarta. Lokasi ini merupakan pusat mobilitas dari wisatawan bisnis di Jakarta. Beberapa stasiun yang menjadi lokasi penelitian, yang dipandang menjadi mobilitas wisatawan bisnis di Jakarta, antara lain Stasiun Lebak Bulus Grab, Stasiun Blok M, Stasiun Senayan, Stasiun Istora, Stasiun Benhil, Stasiun Setiabudi, Stasiun Dukuh Atas, dan Stasiun Bundaran Hotel Indonesia. 
Jenis data yang kemudian ditemukan di dalam penelitian ini adalah data kuantitatif dan data kualitatif. Data kuantitatif merupakan bentuk data yang berbentuk angka sedangkan data kualitatif merupakan data keterangan atau informasi. Penelitian ini menjadi bentuk penelitian kualitatif, dengan maksud mengeksplorasi data yang diperoleh, untuk mengkaji opini, argumentasi, maupun alasan dari subjek penelitian, dalam hal ini informan. Sumber data dalam studi ini adalah data primer. Data primer adalah data yang secara langsung dikumpulkan oleh peneliti, yang diperoleh selama proses pengumpulan data. Dalam memperoleh data primer tersebut, peneliti menggunakan instrumen penelitian di mana peneliti terjun ke lapangan, dan mencatat fenomena yang ada.

Teknik pengumpulan data dilakukan selama dua minggu dengan teknik wawancara mandalam dan teknik participatory observation. Teknik wawancara mendalam digunakan sebagai teknik pengumpulan untuk mengetahui hal-hal dari informan secara lebih mendalam dengan jumlah yang cukup sedikit. Adapun teknik participatory observation dilakukan dengan memfokuskan diri pada konteks sosial budaya, mencari lebih banyak sudut pandang dari informan, mencari sudut pandang perilaku pada waktu dan lokasi yang ditentukan, serta melakukan wawancara maupun pengamatan dengan berperilaku sama seperti informan. Oleh karena itu, dalam proses teknik participatory observation, peneliti melakukan kegiatan yang sama, dengan menyusuri rute MRT yang dilalui oleh informan, sembari mengumpulkan data.

Jumlah informan yang dipilih dalam proses participatory observation dan wawancara mendalam adalah sepuluh orang. Jumlah informan ini dipandang cukup, dengan memperhatikan tingkat kejenuhan data, waktu penelitian, proses analisis deskriptif yang digunakan, dan heterogenitas sudut pandang wisatawan yang menggunakan MRT. Hal ini sejalan dengan pendapat dari Wallen (1993), yang menyebutkan bahwa 
jumlah informan dalam penelitian wawancara dan participatory observation tidak menggunakan batasan pasti, sepanjang dirasa memenuhi kecukupan wakil populasi.

Data yang diperoleh dari hasil penelitian, dianalisis dengan menggunakan model deskriptif. Data-data yang diperoleh kemudian disesuaikan dengan teori PEST (PEST Analysis). Yuksel, (2012:32-40) menyebutkan bahwa analisis ini mencoba mengkaji peran suatu organisasi, yang menggambarkan suatu framework berdasarkan faktor-faktor makro, baik secara internal maupun eksternal, pada proses manajemen strategis. PEST Analysis pada umumnya akan mengkaji beberapa faktor antara lain ekonomi, legal-politik, sosial budaya (socio cultural), dan teknologi dari sisi eksternal, maupun internal (Walden, 2011). Selain melalui PEST Analysis, seluruh data yang diperoleh juga akan direduksi untuk kemudian dideskripsikan melalui business model canvas, untuk memperoleh kesimpulan. Model ini ditemukan oleh Osterwalder (2010:120) dalam disertasinya, yang menggambarkan key partners, key activities, key resources, value propositions, customer relationships, customer segments, dan channels dari suatu bisnis.

Metode analisis ini kemudian menggunakan tiga bentuk tahapan yaitu reduksi data, penyajian data, dan diakhiri dengan menarik kesimpulan. Data yang diperoleh melalui metode participatory observation pun cukup banyak sehingga wajib untuk dicatat secara teliti dan rinci. Dalam analisis deskriptif kualitatif, penyajian data dapat dilakukan dalam bentuk uraian singkat atau sebuah model. Di akhir, peneliti akan menarik kesimpulan dengan melakukan verifikasi. Verifikasi dilakukan melalui proses pencarian makna pada masing-masing setiap fenomena yang diperoleh dari lapangan. 


\section{Tinjauan Pustaka}

MRT merupakan salah satu bagian penting dalam aspek mobilitas dan aksesibilitas, sebagaimana yang disebutkan oleh Cooper (2000:41), empat elemen komponen pariwisata adalah attraction, accessibility, amenity, ancillary (4A). Peran krusial dari transportasi publik, seperti MRT, dalam sektor pariwisata, menjadi landasan beberapa penelitian sejenis yang pernah melakukan kajian mengenai peran penting sektor pariwisata, bagi industri pariwisata. Kovacic (2016:99) menyebutkan bahwa moda transportasi saat ini tidak hanya bertujuan sebagai aksesibilitas semata, melainkan juga sebagai atraksi wisata itu sendiri. Wisatawan sudah menggunakan indikator moda transportasi sebagai salah satu faktor penarik minatnya berkunjung ke suatu destinasi. Penelitian kualitatif ini juga membahas pentingnya analisis secara berkala, untuk mengkaji peran alat transportasi, bagi pariwisata berkelanjutan disebuah destinasi.

Penelitian selanjutnya dikemukakan oleh Palhares (2003:403407), yang menggambarkan peran krusial moda transportasi dalam pembangunan pariwisata. Penelitian ini merekomendasikan perspektif dalam riset transportasi untuk sektor pariwisata, melalui disiplin ekonomi, geografi, manajemen, psikologi, atau sosiologi, tanpa melalui pendekatan multidisiplin. Rekomendasi pentingnya proses kemitraan (partnership) juga diberikan, melalui proses pemasaran, promosi, aliansi, atau program loyalitas), antara moda transportasi, bersama dengan destinasi pariwisata atau sarana pendukung pariwisata lainnya. Ilustrasi dari penelitian ini menunjukkan betapa krusialnya model sinergi antar moda transportasi, yang ada di Bangkok dan Singapura, yang mampu membangun sebuah jejaring pasar pariwisata.

Penelitian berikutnya disampaikan oleh Mammadov (2012:381), yang mengemukakan beberapa rekomendasi dalam rangka meningkatkan 
peran moda transportasi, bagi industri pariwisata di suatu negara. Rekomendasi tersebut antara lain: pentingnya menentukan moda transportasi secara spesifik yang ingin dikembangkan, pentingnya penentuan harga yang kompetitif, menariknya moda transportasi berbasis rel dibandingkan moda transportasi lainnya, serta alokasi finansial untuk pembangunan infrastruktur transportasi, serta sumber daya manusia.

Shah (2019:7) menyebutkan bahwa moda transportasi yang mampu mendukung sektor pariwisata, hendaknya memenuhi beberapa syarat berikut, seperti waktu, jarak, kenyamanan, harga, tingkat kompetitif, hingga manfaat yang akan diperoleh oleh wisatawan ketika berwisata. Dewantara (2019:141), menyampaikan bahwa moda transportasi membutuhkan sisi inovasi dan kreativitas, untuk memastikan aksesibilitas terbaik bagi wisatawan. Sistem transportasi yang baik akan memudahkan mobilitas wisatawan dan pengunjung, serta sumber daya pendukung lainnya.

\section{Hasil Penelitian dan Pembahasan}

Hasil penelitian menunjukkan adanya peran penting bagi moda transportasi MRT untuk aksesibilitas wisatawan, khususnya pariwisata bisnis di Jakarta. Keberadaan MRT yang cukup dengan pusat-pusat bisnis, menjadi salah satu alasan wisatawan mulai beralih dari kendaraan pribadi, ke MRT. Berikut adalah penjabaran masing-masing bentuk peranan MRT.

a. Ekonomi

Dari sisi ekonomi, MRT Jakarta dipercaya mampu mendukung pertumbuhan ekonomi, sekaligus mempercepat pembangunan infrastruktur. Dekatnya stasiun MRT dengan pusat-pusat perekonomian, menarik minat wisatawan bisnis (business traveler), untuk semakin gencar melaksanakan aktivitas bisnisnya di Jakarta. Saat pembangunan MRT baru dimulai, memang sudah ada banyak 
ribuan pekerja yang ikut serta membantu dalam proyek pembangunan MRT. Sistem MRT yang terencana juga memberikan warna baru dalam tata ruang perencanaan kota. Sistem pembayaran yang tanpa menggunakan uang tunai (cashless), dipercaya mampu menyederhanakan proses transaksi selama memesan tiket di stasiun MRT. Hal tersebut memberikan sisi kenyamanan bertransaksi, khususnya wisatawan asing yang baru saja datang ke Jakarta. Bulan Mei-Juli 2019, menurut data dari PT. MRT Jakarta, MRT telah mengantongi keuntungan 50,4 miliar yaitu sebesar 30\% dari pendapatan yakni Rp168 miliar.

Bagi wisatawan asing, MRT disebut dapat sebagai daya tarik masyarakat Indonesia, terutama yang berasal dari luar negeri, untuk mencoba infrastruktur baru tersebut yang dapat mempengaruhi perekonomian Jakarta dan juga negara. Wisatawan domestik juga cukup kagum dengan keberadaan MRT, yang memberikan warna baru bagi prestise negara Indonesia, kepada khalayak asing.

Adapun dari sisi eksternal, informan berpendapat bahwa keberadaan MRT dapat memberikan dampak ekonomi dari sisi luar. Apabila terjadi deflasi maupun inflasi, maka harga tiket MRT pun akan mudah terpengaruhi. Hal ini bisa amat berdampak pada jumlah penumpang yang menggunakan moda MRT, sekaligus bagi minat wisatawan. Dampak lainnya muncul dari kebijakan fiskal dan moneter yang bertujuan menstabilkan perekonomian Indonesia, yang berpengaruh juga kepada kondisi perekonomian perusahaan MRT. Kemajuan percepatan pembangunan MRT juga sangat dipengaruhi percepatan pembangunan Indonesia dalam beberapa tahun ke depan. "MRT sudah memberikan warna baru bagi ibukota Indonesia, dan menarik banyak pebisnis untuk semakin tertarik bertransaksi, sekaligus berwisata di Jakarta" Informan-1 
b. Legal Politik

PT. MRT Jakarta dipandang sebagai perusahaan yang mematuhi kode etik dan mematuhi peraturan perundangan, khususnya di bidang lingkungan. PT. MRT Jakarta saat ini dimiliki oleh perusahaan milik daerah, sehinga tidak ada hubungan sama sekali dengan partai politik manapun dan harus bersikap netral. Netralitas suatu perusahaan dirasa penting bagi wisatawan pebisnis, sekaligus penting dalam menjalankan kegiatan corporate social responsibility (CSR) ke depannya.

Hal yang lebih penting lainnya adalah kemampuan MRT dalam memenuhi seluruh aspek legal-formal selama proses konstruksi, hingga saat proses operasional. Wisatawan internasional sangat tertarik untuk menggunakan layanan MRT, demi mengurangi tingkat polusi udara, maupun polusi bunyi di ibukota. Sseluruh energi yang digunakan dalam operasional MRT menggunakan energi listrik, sebagian menggunakan sumber daya listrik bertenaga matahari, serta sisanya adalah energi listrik bertenaga uap. Sifat MRT yang ramah lingkungan tentu sangat didukung oleh wisatawan. Kondisi MRT juga didukung sistem serta kondisi politik dan hukum yang ada di lingkungan sekitar perusahaan MRT Jakarta. Mengingat MRT Jakarta cukup dekat dengan pusat-pusat strategis negara, maka penjagaan yang ketat selalu diterapkan oleh otoritas kepolisian. Hal ini terbukti pada beberapa aksi demonstrasi besar di Jakarta, yang sama sekali tidak mengganggu operasional MRT. Pemerintah juga menyiapkan MRT dengan beberapa peraturan yang kuat dan mengikat, untuk menjamin tingkat keamanan para pelanggan MRT. Hal ini juga menjadi salah satu pertimbangan wisatawan memilih MRT, dibandingkan dengan moda transportasi publik lainnya seperti kereta api listrik (KRL), atau bus TransJakarta. 
Proses operasional MRT juga menggunakan sistem keamanan yang super ketat, di mana seluruh penumpang diwajibkan untuk dicek melalui metal detector, sebelum memasuki stasiun. Tingkat keamanan lainnya adalah kamera CCTV di sepanjang stasiun, jarak pengaman antar gerbong kereta dan ruang tunggu, hingga kesiapsiagaan petugas pengaman pada beberapa titik tertentu. Tingkat keamanan yang sangat ketat mengeliminasi adanya tindakan kriminal, yang menjadi prasyarat bagi wisatawan asing untuk menggunakan suatu moda transportasi.

"Aspek keamanan selalu menjadi concern kami sebagai wisatawan ketika berkunjung ke Jakarta, dan MRT mampu menjawab itu" Informan-2

c. Sosial Budaya (Socio Cultural)

Kehadiran MRT di kawasan Jakarta berpengaruh besar dalam kehidupan masyarakat Jakarta terutama dalam aspek sosial budaya. Beberapa wisatawan menyebutkan bahwa keberadaan MRT telah membentuk suatu peradaban baru bagi ekosistem Jakarta, baik penduduk lokal maupun pendatangnya. MRT di Jakarta telah menekankan pentingnya budaya mengantri, budaya hidup bersih, dan budaya tertib dalam berlalu lintas. Wisatawan yang sedang berkunjung ke Jakarta juga menggunakan MRT agar dapat bebas dari kemacetan. Dengan dibangunnya MRT, masyarakat menjadi lebih bisa untuk belajar nilai luhur budaya bangsa, yang telah hilang. Budaya leluhur tersebut antara lain tanggung jawab dalam bermasyarakat, budaya mengantri, disiplin, dan ketertiban.

Di sisi lain, wisatawan berpandangan bahwa dengan dibangunnya MRT, dan menggunakan MRT, adalah salah satu wujud dalam membantu kelangsungan lingkungan hidup, yang ada di Jakarta, karena sumber tenaga yang digunakan MRT adalah listrik, dan tidak menggunakan bahan bakar sehingga tidak menimbulkan polusi udara, wisatawan asing merasa sudah membantu sebagian warga Jakarta 
hidup dalam kondisi lebih sehat. Wisatawan juga merasakan dapat membantu seluruh rakyat Indonesia, untuk pelan-pelan beralih dari bahan bakar minyak berbahan dasar fosil (fossil fuel).

Wisatawan asing merasakan bahwa kebiasaan wisatawan seringkali digunakan sebagai role model oleh kebiasaan-kebiasaan warga Jakarta. Kebiasaan wisatawan asing menggunakan MRT, diharapkan dapat membudayakan warga menengah atas Jakarta, untuk lebih memilih menggunakan transportasi publik, dibandingkan transportasi pribadi. Akan tetapi, wisatawan asing terkadang cukup terganggu pada akses MRT ke beberapa apartemen, atau pusat bisnis pertokoan, yang tidak melindungi diri dari hujan, serta mengganggu keselamatan. Aspek sosial ini menjadi hal yang harus diperhatikan oleh pengelola MRT, agar wisatawan dapat lebih nyaman dalam menggunakan moda ini.

Di saat yang bersamaan, wisatawan asing juga berharap adanya peningkatan kesadaran masyarakat dalam pengunaan transportasi umum, khususnya untuk mengurangi kemacetan di jalan raya. Penggunaan moda transportasi publik di Indonesia dirasa cukup rendah, jika dibandingkan dengan negara Eropa atau negara lainnya. Wisatawan berharap masyarakat mampu menurunkan gengsi ketika menggunakan transportasi publik. Di sisi lain, pengelola MRT diharapkan mampu mensosialisasikan pentingnya naik MRT pada beberapa pusat bsinis.

"Kebiasaan orang Jakarta yang tidak menggunakan MRT lebih disebabkan oleh gengsi, dan gaya hidup mereka yang lebih menyukai menggunakan kendaraan pribadi. Hal ini tidak terjadi di Eropa" Informan-3

d. Teknologi

Keberadaan MRT menunjukkan citra Indonesia sebagai negara yang siap dalam pengembangan teknologi berbasis transportasi, 
sekaligus mampu bersaing dengan negara lainnya. Wisatawan menyebutkan beberapa kecanggihan teknologi, seperti transaksi pembayaran, deteksi keamanan, dan kepastian perjalanan, menjadi beberapa keunggulan dari MRT dibandingkan dengan moda transportasi sejenis di luar negeri.

Sayangnya, MRT belum mampu menjawab sinergitas antara moda transportasi dengan destinasi wisata, dan destinasi MICE utama wisatawan pebisnis di Jakarta. Hal ini menjadi pekerjaan rumah pengelola MRT, bersama pengelola destinasi, dan bisnis-bisnis terkait. MRT juga belum mampu bersinergi dengan event-event besar tujuan utama pebisnis di Jakarta, seperti pameran mobil, pameran pendidikan, atau pameran properti.

Di sisi lain, teknologi yang digunakan MRT sangat ampuh membantu wisatawan untuk melakukan perjalanan menjadi lebih cepat, tanpa terjebak kemacetan. Sebagai contoh, sebelum dibangunnya MRT, untuk berangkat dari Lebak Bulus menuju bundaran Hotel Indonesia biasanya membutuhkan waktu sekitar 1,5 jam. Namun saat ini, dengan menggunakan MRT hanya memakan waktu sekitar 30 menit. MRT ini dilengkapi dengan teknologi keselamatan tingkat tinggi, teknologi parkir di stasiun MRT tertentu, teknologi informasi jadwal keberangkatan dan kedatangan, serta teknologi pembayaran.

"Teknologi yang ditawarkan oleh MRT bisa dikembangkan lagi, khususnya dari sisi kemudahaan akses ke suatu event" Informan-4

Peran penting MRT dari sudut pandang eksternal pengguna (external user) tampak jelas dari struktur analisis PEST di atas. Akan tetapi, dari sisi internal, berdasarkan hasil wawancara dan participatory observation, peran MRT dalam mendukung industri pariwisata bisnis akan lebih mudah tergambar dari business model canvas berikut ini. 
Business Model Canvas

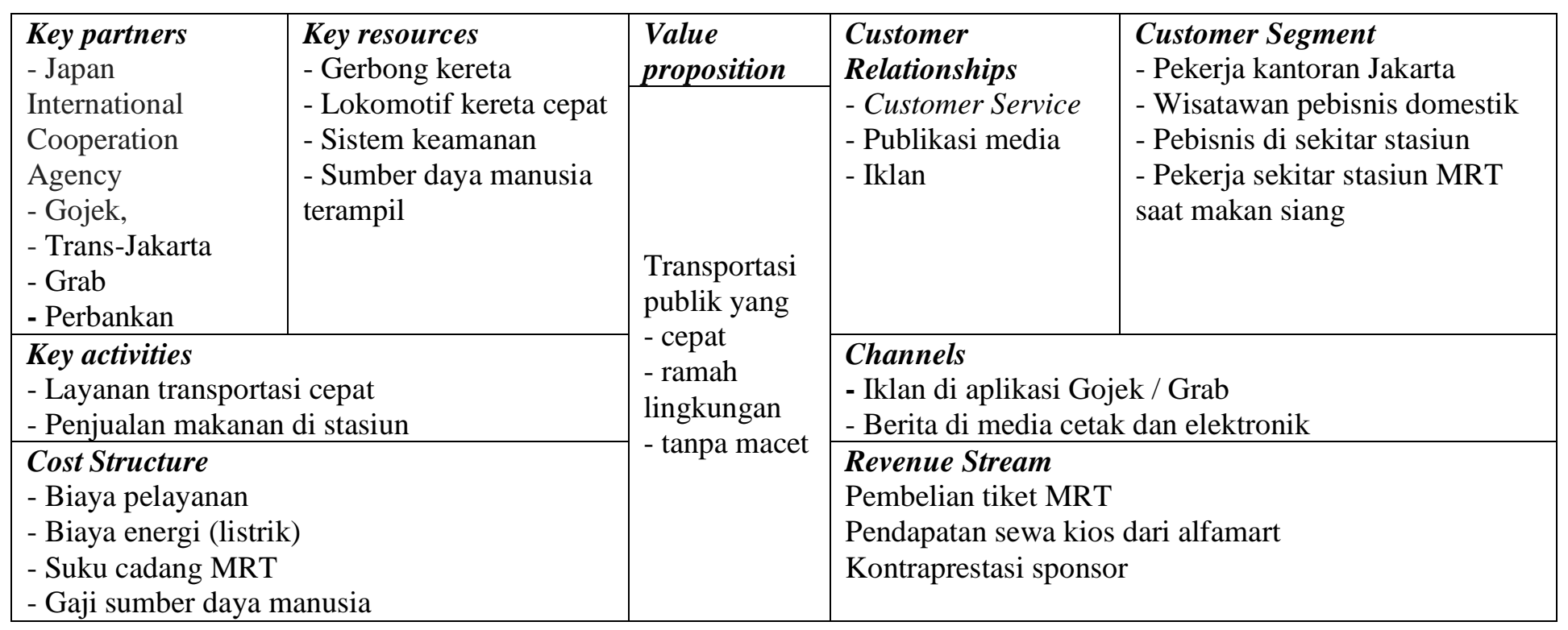




\section{a. Value proposition}

Nilai tambah atau sisi pembeda dari MRT Jakarta tampak jelas jika dibandingkan moda transportasi publik lainnya yang ada di Jakarta. Biasanya, untuk kebutuhan pariwisata, pemerintah Jakarta mengandalkan kereta api listrik (KRL), bus Transjakarta, dan taksi sebagai moda transportasi utama. Ketiga moda transportasi tersebut masih mengalami kendala seperti sering terjebak macet, bahan bakarnya masih mengandung kandungan gas berbahaya, dan berjalan tidak cepat. Hal ini seakan dijawab oleh sisi pembeda MRT Jakarta, di mana transportasi ini mengandung sisi pembeda yaitu transportasi publik yang cepat, ramah lingkungan, dan tanpa macet. Hal ini juga sejalan dengan visi MRT Jakarta yaitu "Moving Jakarta into one of the leading modern cities in Asia with the world class standards of operational excellence", mendorong Jakarta sebagai kota modern terdepan di Asia, dengan standar operasional yang sempurna berkelas dunia. Untuk mewujudkan visi MRT Jakarta, dicetuskanlah misi MRT Jakarta yaitu "Providing Sustainable Excellence Service in Mass Rapid Transportation in a safe, convenient and reliable manner" atau menyediakan pelayanan prima yang berkelanjutan, dalam transportasi cepat berskala besar, yang aman, nyaman, dan dapat diandalkan.

b. Cost Structure

Struktur biaya dari penyelenggaraan operasional MRT Jakarta mencakup biaya pelayanan, biaya energi khususnya listik, suku cadang MRT, dan gaji untuk sumber dana manusia. Struktur biaya tidak terlalu dikendalikan dalam rangka meningkatkan pelayanan kepada pelanggan. Wisatawan merasa bahwa pemeliharaan sarana dan prasarana MRT sudah cukup baik, di mana sejauh ini, MRT Jakarta tidak pernah terkendala kemacetan. Di sisi lain, wisatawan bisnis di Jakarta mengapresiasi bentuk pelayanan serta profesionalitas petugas 
MRT Jakarta, yang selalu siap siaga dalam menyampaikan informasi. Keramahtamahan juga dipandang sebagai salah satu poin penting yang dimiliki pegawai di MRT Jakarta.

c. Key partners

Untuk menjalankan proses bisnisnya, MRT Jakarta bekerjasama dengan beberapa mitra kunci. Proses kemitraan dilakukan untuk mempermudah proses pelayanan dengan pihak konsumen. Mitra kunci dari MRT Jakarta antara lain: Japan International Cooperation Agency, Gojek, Trans-Jakarta, Grab, serta industri Perbankan. Wisatawan cukup merasakan kemitraan yang dilakukan MRT Jakarta, khususnya dalam hal kemudahan pembayaran via kartu milik Perbankan nasional. Selain itu, kemitraan MRT Jakarta dengan Gojek dan Grab juga mempermudah wisatawan dalam melanjutkan perjalanan ke destinasi wisata, atau pusat bisnis yang dituju. Akan tetapi, wisatawan berpendapat agar proses kemitraan dapat ditingkatkan lagi dengan Trans-Jakarta, maupun industri perhotelan dan daya tarik wisata di Jakarta. Hal ini untuk memperlancar kegiatan wisata bisnis yang dilakukan wisatawan selama di Jakarta.

d. Key resources

Sumber daya utama dalam menjalankan operasional serta pelayanan di MRT Jakarta adalah kereta berupa lokomotif dan gerbong kereta. Sistem perkeretaapian kemudian didukung oleh adanya sistem keamanan yang terjamin, serta sumber daya manusia terampil. Wisatawan berpendapat bahwa kondisi kereta dan stasiun sudah cukup bersih, dan aman. Hal ini membuat wisatawan semakin nyaman ketika berada di dalam stasiun maupun kereta. Sayangnya, wisatawan berpendapat agar pihak pengelola juga memperhatikan jalur dari stasiun MRT menuju pusat bisnis, agar dapat diberikan atap peneduh, atau diintegrasikan secara langsung. Salah satu contohnya adalah 
integrasi stasiun Bundaran Hotel Indonesia, dengan Plaza Indonesia dan Grand Indonesia.

e. Key activities

Aktivitas utama dari MRT Jakarta adalah layanan transportasi secara cepat dan tepat waktu. Selain itu, aktivitas utama yang ditawarkan adalah penjualan makanan di sepanjang areal stasiun. Wisatawan berpandangan bahwa ada baiknya pihak manajemen stasiun MRT menggelar pertunjukan budaya di stasiun bawah tanah MRT. Selama ini, wisatawan cukup jarang terinformasikan mengenai potensi budaya yang ada di Jakarta. Pertunjukan seni tari, seni lukis, atau seni musik dipandang mampu menghibur wisatawan yang sedang berlalulalang di Jakarta.

f. Revenue Stream

Saat ini MRT Jakarta tidak terlalu menargetkan pendapatan di beberapa tahun awal operasionalnya. Hal ini mengingat rute minim yang baru disediakan, dan belum tingginya minat masyarakat atau wisatawan menggunakan MRT. Pendapatan utama MRT memang diperoleh dari penjualan tiket pengguna MRT. Di sisi lain, pendapatan juga muncul dari kesepakatan kemitraan berupa dana kontraprestasi dari pihak sponsor. Penyewaan toko di dalam area stasiun juga menjadi salah satu sumber pendapatan MRT Jakarta. Sejauh ini, diperkirakan 10.000 orang menggunakan MRT Jakarta setiap harinya, dari 5 juta orang yang bepergian dari pinggir kota ke ibukota Jakarta.

\section{g. Customer Relationships}

Wisatawan merasakan belum merasa terinformasi cukup sering, dan mendetail mengenai keberadaan MRT Jakarta. Banyak informasi justru diperoleh dari publikasi media, yang kemudian menggugah keingintahuan wisatawan untuk menggunakan MRT. Di sisi lain, MRT Jakarta juga cukup sering menggunakan media iklan, 
baik cetak di baliho maupun surat kabar, serta media elektronik, dalam menjalin hubungan dengan pelanggannya. MRT Jakarta juga memiliki layanan customer service untuk memastikan kenyamanan pelanggan, melalui penyebaran angket berkala.

h. Channels

Untuk menjalin hubungan dengan pihak pelanggan, dan menargetkan pelanggan baru, MRT Jakarta cukup rutin dalam menyampaikan iklan, khususnya di aplikasi Gojek maupun Grab. MRT Jakarta juga cukup gencar dalam memberikan informasi di media cetak dan elektronik. Wisatawan berpandangan bahwa MRT Jakarta dapat memperlebar jejaringnya, dengan menginformasikan detail produk pada hotel-hotel tempat wisatawan menginap, pusatpusat pertemuan dan gedung pertemua, serta di maskapai penerbangan, atau stasiun kereta api. Sebagian besar wisatawan yang datang di Jakarta menggunakan moda pesawat terbang.

i. Customer Segment

PT.MRT Jakarta menargetkan kepada para pekerja yang biasanya diwajibkan untuk memiliki mobilitas yang cepat dalam berpindah dari satu tempat ke tempat lain. MRT Jakarta juga dipandang memberi solusi pada para pebisnis dari luar negeri, yang ingin melakukan kegiatan bisnis di Jakarta, pada jam-jam sibuk. Pebisnis tersebut biasanya berkantor di area-area sekitar stasiun, seperti seputar Jalan Sudirman. Pebisnis domestik yang sekaligus menjadi wisatawan ketika melakukan aktivitas bisnis juga menjadi segmen pelanggan dari MRT Jakarta. Tidak hanya para pekerja yang berangkat maupun pulang dari kantor, keberadaan MRT Jakarta juga membantu para pekerja yang ingin bertemu rekannya saat jam makan siang, khususnya di areal sekitar stasiun MRT. 


\section{Simpulan dan Saran}

MRT Jakarta merupakan jenis transportasi yang sangat cocok dan memiliki arahan yang jelas dalam menargetkan peningkatan kualitas hidup masyarakat, maupun memperlancar aksesibilitas wisatawan selama berwisata, maupun berbisnis di Jakarta. MRT Jakarta pun telah mampu menciptakan kemajuan perekonomian di sekitar lingkungan sekitar MRT. MRT juga memulihkan tata ruang kota, berperan sebagai penyumbang devisa negara, dan membuat kawasan sekitar Jakarta berkembang. Hal ini menjadi salah satu media pendorong wisatawan untuk tinggal di Jakarta lebih lama. MRT Jakarta juga telah mengubah cara berperilaku dan mengubah peradaban masyarakat Jakarta, untuk lebih tertib, disiplin, dan menyukai transportasi publik. Hal ini akan mengurangi potensi polusi udara dan bunyi di Jakarta. Pengurangan polusi secara masif akan membuat wisatawan yang berkunjung ke Jakarta menjadi semakin nyaman.

MRT juga telah memberikan contoh moda transportasi yang mampu menggunakan bahan bakar yang ramah lingkungan sehingga dapat mencegah polusi udara dan juga menghemat bahan bakar minyak. Dengan teknologi pembayaran yang mudah, serta kebersihan dan keamanan yang terjaga, MRT Jakarta diperkirakan akan menjadi primadona para wisatawan, baik yang sedang berbisnis, maupun yang sedang menikmati daya tarik wisata di ibukota Jakarta.

PT MRT Jakarta telah memberikan banyak manfaat bagi lingkungan dan telah menunjukkan dalam statistik bahwa total 10.000 penumpang menggunakan MRT sebagai media transportasi setiap hari. Hal ini sebenarnya masih jauh dari total jumlah 5 juta orang yang bepergian dari pinggir kota Jakarta (seperti Bogor, Tangerang, Depok, dan Bekasi), ke ibukota Jakarta. Terdapat beberapa cara agar perusahaan dapat menarik minat wisatawan dalam menggunakan MRT seperti 
mensinergikan tiket MRT dengan daya Tarik wisata lainnya. Hal ini akan membuat wisatawan lebih dipermudah dan termotivasi untuk bepergian dengan MRT, dan sekaligus menjadi contoh bagi warga lokal Jakarta. MRT Jakarta juga dapat meningkatkan kegiatan kampanye dan kegiatan pemasaran, melalui peningkatan kesadaran tentang lalu lintas dan kampanye berkendara yang ramah lingkungan. Proses kampanye dapat disebarkan melalui media yang lekat dengan wisatawan, seperti majalah di pesawat terbang, bandara, dan stasiun.

PT MRT Jakarta juga harus mengambil keuntungan dari kemajuan teknologi, dan mengaktifkan kampanye media sosial secara rutin. PT MRT Jakarta dapat menonjolkan kelebihannya, yaitu kebersihan, kecepatan, dan keamanan, yang biasaya menjadi pertimbangan wisatawan asing dalam memilih moda transportasi. Di saat yang bersamaan, PT MRT Jakarta diminta untuk tetap melanjutkan proses konstruksi rel berikutnya, sembari mempertahankan standar pelayanan prima yang selama ini sudah diterapkan.

\section{Daftar Pustaka}

Cooper, Chris Cs., (2000). Tourism: Principles and Practice. Second Edition, Longman, England.

Dewantara, Made Handijaya. (2019). Peran Gojek Sebagai Akses Publik Wisatawan di Bali dan Pelopor Ekonomi Kreatif. JUMPA Volume 6, Nomor 1, Juli 2019, 141 - 156.

Kovacic, Mirjana \& Milosevic, Tamara. (2016). Interdependence of Transport and Tourism. Journal of Pomorski Zbornik 52 (2016), 99111.

Mammadov, Rufat. (2012). The Importance of Transportation in Tourism Sector. 7th Silk Road International Conference "Challenges and Opportunities of Sustainable Economic Development in Eurasian Countries".

Osterwalder, Alexander. (2010). Business Model Generation: A Handbook for Visionaries, Game Changers, and Challengers. New Jersey: Wiley. Palhares, Guilherme. (2003). The Role of Transport in Tourism Development: Nodal Functions and Management Practices. International Journal of Tourism Research, Res.5, 403-407. 
Pemerintah DKI Jakarta. (2008). Peraturan Daerah Provinsi Daerah Khusus Ibukota Jakarta Nomor 3 Tahun 2008, tentang Pembentukan Badan Usaha Milik Daerah (BUMD), Perseroan Terbatas (PT) MRT Jakarta.

Shah, Abdur. (2019). The Importance of Transportation to Tourism Development. International Journal of Tourism and Hotel Management 2019; 1(1): 07-09.

Wallen, N. \& Fraenkel, J. (1993). How to Design and Evaluate Research in Education. New York: McGraw-Hill Inc.

Walden, Joseph. (2011). Comparison of the STEEPLE Strategy Methodology and the Department of Defense's PMESII-PT Methodology. Report of Supply Chain Leadership Institute 2011.

Yuksel, Ihsan. (2012). Developing a Multi-Criteria Decision Making Model for PESTEL Analysis. International Journal of Business Management, Vol 7. No. 24, 2012. 
Made Handijaya Dewantara

24 JOURNEY Volume 2 Nomor 2, Juni 2020 